\title{
Appendix
}

\section{PEOPLE FEATURED}

AKsana Worked as an exotic dancer in Istanbul for short contracts over nearly five years; returned home to Belarus, and dreams of realizing aspirations of her youth to become a classical dancer.

ANDREI Looking toward retirement, Andrei continues to work for the Vulcăneşti municipality.

ANiA Became a significant player in the import business from the garment district in Istanbul, regularly expending up to $\$ 10,000$ in purchases.

BeLla After moving to Moscow she ran a thriving business renovating apartments and enjoyed annual visits to her sons and grandson in Romania. In 2016 she decided not to pursue permanent residency in Russia, and instead moved to Romania to live with her sons.

Eva Nearing retirement from her work at the town hospital in Vulcăneşti, she now travels twice a year to spend several months with her grandchildren in Russia.

GALINA Ran a stall selling clothing at a market in a city to the south of Moscow; she continues to sing and sell food at the market.

IRINA Worked as an exotic dancer in Istanbul for two years and ultimately married a German she met in one of the clubs. Moved to Germany with her daughter and became a housewife.

IULIA After dropping out of law school in Russia, worked as an exotic dancer in Istanbul for a short contract; returned to Russia where she still dreams of pursuing a career in acting. 
KARA Worked as an exotic dancer in Istanbul for several years, supporting her mother and brother at home in Ukraine. She married and moved to Bulgaria where she works in a grocery store while raising her school-age son.

MARIA For more than twenty years she worked as a shop assistant and later sales manager in Laleli; in 2014 her husband passed away, and Maria decided to move to Moscow to live with her daughter and grandchildren.

NAdia Arrived in Istanbul in the late 1990s and was able to capitalize on the relatively well-paid work as an entertainer; in the early 2000s she opened her own property management company with her boyfriend as a business partner.

NeLli Raised her granddaughter while her daughter, Niki, was in Turkey, and now enjoys periodic visits from her granddaughter who studies in Romania.

Niki After years of living in Turkey in 2011 Niki returned briefly to Moldova and eked out a living shuttling goods from Romania into Moldova. After receiving her Bulgarian citizenship in 2013, she left to work in Great Britain.

Olga After starting a small shuttle trading business, she prospered. She expanded her boutique and now has a chain of men's clothing stores in the suburbs of Moscow.

Polina Works in Laleli as a shop assistant as she has since the late 1990s; she lives happily with her Turkish boyfriend and makes yearly visits to her grandchildren in Ukraine.

RAIA Worked as a sales assistant in Istanbul for two years and hoped to marry her boyfriend. She has returned to live with her parents and son in Moldova.

Zhenia Central Siberian shuttle trader and former teacher. Passed away in the early 2000s.

ZINA Worked as an itinerant domestic worker and shop assistant in Istanbul and as a projectionist and medical orderly in Moldova. She now works as a domestic in Moscow, where she often cares for her granddaughter. She dreams of finding an Indian husband. 